\title{
The Determinants of Return Migration: Evidence for Kosovo
}

\section{Ardiana Gashi}

Fakulteti Ekonomik, University of Prishtina, Kosovo

ardianag@mail.com

\section{Nick Adnett}

Staffordshire University, Business School, UK

N.J.Adnett@staffs.ac.uk
CroEconSur

Vol. 17

No. 2

December 2015

pp. $57-81$

Received: February 2, 2015

Accepted: October 2, 2015

Research Article

doi:10.15179/ces.17.2.2

\section{Abstract}

Return migration represents a potentially important contributor to economic development for countries that are large exporters of labor. This paper provides an analysis of the determinants of return migration to Kosovo, a country with an especially high level of recent emigration. The findings of this investigation suggest that there is a non-linear relationship between the age of the migrant and their probability of returning. In addition, the more educated migrants and those that have acquired additional education whilst abroad are more likely to return, whereas recent migrants, those that possess permanent resident status and have their family abroad are less likely to return. As expected, the stronger the family ties of a migrant with their home country, the more likely they are to return. Finally, migrants that are expected to invest in businesses in Kosovo are more inclined to return. Together these findings suggest that return migration may be 
an important contributor to economic development in Kosovo and policies are outlined that could strengthen this contribution.

Keywords: return migration, education, investment, development

JEL classification: F22, J6, I25

\section{Introduction'}

Large scale emigration has been a key feature of Kosovo's economy in recent decades and remittances account for between 10 and 15 percent of the country's GDP (International Monetary Fund, 2013). There are no agreed figures for the number of Kosovo emigrants, though according to the 2011 Population Census (Kosovo Agency of Statistics - KAS, 2012a) there were nearly 400,000 Kosovo citizens living abroad, equivalent to around 23 percent of the total population (KAS, 2012b). However, this number may be considered an underestimation as it excludes the children of those that were born in Kosovo and live in other countries. Based on emigration between 1981 and 2011, the 2014 Kosovo Human Development Report (UNDP, 2014) estimates that there were up to 874,000 Kosovo migrants. Whilst the contribution of remittances to development has been the focus of a number of studies of migrants (Bhaumik, Gang and Yun, 2006; Shaorshadze and Miyata, 2010; UNDP, 2010, 2012; World Bank, 2011; Duval and Wolff 2013; KAS, 2013), it has proved difficult to establish their specific contribution to the home country's economic development (Clemens and McKenzie, 2014). A largely neglected but potentially important additional contributor to a country's economic development is the return migration (Clemens, Ozden and Rapoport, 2014, Dustmann and Görlach, 2015). The determinants of return migration have been relatively under-researched at country and cross-national levels, a neglect which has been largely attributed to

1 This article has been supported by the World Bank, to whom the authors are grateful. The views in this paper are those of the authors and do not reflect those of the World Bank. This paper has benefitted from the helpful comments of two anonymous referees. 
a lack of appropriate data (OECD, 2008; Plaza and Ratha, 2011). In this paper we investigate those determinants using recent survey data of intentions of return migration for Kosovo.

Previous research on return migration has identified three main channels through which return migrants can facilitate the economic development of their home country. The first channel is through their accumulated financial capital which can be invested upon return (McCormick and Wahba, 2001; Piracha and Vadean, 2010; De Vreyer, Gubert and Robilliard, 2010) and facilitate the transfer or adoption of new technologies (Agunias, 2006; Plaza and Ratha, 2011). The acquired knowledge, skills and familiarity with latest technologies which can be utilised upon return provide a second channel (Zweig, Chung and Vanbonacker, 2006; Mahuteau and Tani, 2011; Kuschminder and Butcher, 2012). Thirdly, the augmented social capital of return emigrants can stimulate economic development through establishing new networks and challenging and displacing traditional norms and values (Zweig, 2005; Black, King and Tiemoko, 2003).

Policies that target increasing the contribution of return migration to home country development can be classified into three broad groups. The first group contains policies that aim to reduce the informational, bureaucratic and regulatory barriers faced by potential return migrants. The second group provides financial or other incentives to returnees, and the final group targets their reintegration into society and raising their labor market productivity. Recognizing the potentially important role that return migrants may play in their home country, this study examines the determinants of return migration and then considers the policy implications of those findings.

The model utilized in the empirical analysis is eclectic, based on an amalgam of the theoretical approaches previously employed in this field, i.e., neoclassical economics, the new economics of labor migration, structuralism, transnationalism and social network theory. To empirically examine the hypotheses developed from these frameworks, a binary probit model is employed. 
Three main groups of explanatory variables are included. The first group consists of individual characteristics of migrants (gender, age, location); the second consists of variables recording the experience of the migrant in the host country (employment status, duration of stay, acquired education whilst abroad, etc.) and the third group comprises variables that may measure the preparedness of the migrant for return (whether the migrant invested in real estate, frequency of visits to the home country, plans to invest in future, if they remit to the family).

The next section outlines the theoretical framework underlying the empirical analysis of the determinants of return migration. The following sections investigate the nature of the data, explain the methodology adopted and elaborate the main findings. The conclusions and policy implications are outlined in the final section.

\section{A Theoretical Framework for Analyzing the Determinants of Return Migration}

As noted above, return migration has previously been analyZed through a variety of approaches: neoclassical economics, the new economics of labor migration, structuralism, transnationalism and social network theory. These approaches will be briefly reviewed in this section and then used to develop a framework for specifying the econometric model.

According to orthodox theory, return migration, in accordance with the assumption of individual utility maximisation, is predominantly determined by wage differentials between receiving and sending countries, together with migrants' expectations and experience of earnings in the host country (Todaro, 1969; Cassarino, 2004 and 2008). This suggests that return migration involves disproportionately those labor migrants who have underestimated the ongoing costs of migration or overestimated the expected benefits from migrating (Borjas and Bratsberg, 1996). A further reason for returning may be that relative labor market conditions in host and home countries may have changed in favor of 
the latter. For example, Bijwaard and Wang (2013) found that unemployed previously foreign students in the Netherlands were more likely to return than those in employment.

In addition, return migrants will include those who have only anticipated a finite stay in the host country, perhaps due to meeting their savings target, or the increasing costs associated with migration duration or completing planned investments in the acquisition of skills or expertise which are particularly scarce in their home country. According to the new economics of labor migration (NELM), this type of return migration is a logical outcome of a 'calculated strategy', which results from the successful achievement of goals while abroad, i.e., higher incomes, accumulation of savings and human capital (Cassarino, 2004). Bijwaard and Wang (2013) found evidence of such target-setting behavior amongst returning previously foreign students in the Netherlands. The NELM theory also considers remittances as part of the 'calculated strategy', since remittances contribute to income risk diversification in the home country households, relax budget constraints, improve living conditions, and consequently enable the household to invest and hedge against risks resulting from inefficient insurance markets in the home country (Stark and Taylor, 1991). According to the NELM, when these migration-related goals are achieved, there is no reason for a migrant to remain abroad and hence the decision to return (Stark and Levhari, 1982; Katz and Stark, 1986; Cassarino, 2004). The NELM theory also introduces the existence of attachment to the home country. Dustmann (2003) and Dustmann and Weiss (2007) make the assumption that consumption at home is preferred to consumption abroad, other things being equal, and that an increase in migration duration increases the cost of forgone consumption at home. Consequently, the difference between the marginal benefits and costs of staying another period in the host country decreases (and may become negative), even when persisting wage differentials favor the host country.

According to the NELM theory, another motive for migration is relative deprivation, implying that migration not only occurs to improve income in 
absolute terms, but also to increase income relative to others in the country of origin (Stark, 1984; Stark and Yitzhaki, 1988, Stark and Taylor, 1991, Carletto et al., 2004). A number of micro-level empirical tests have supported the hypothesis that relative deprivation does increase migration propensities in sending communities (Bhandari, 2004; Quinn, 2006; Stark and Taylor, 1989; Stark and Taylor, 1991). With regard to return migration, it may be expected that the longer the migration duration, the greater the chances that relative deprivation has declined or even reversed, hence the greater the propensity of the migrant to return home.

The network theory approach stipulates that return migration is more likely to occur in the early stages of migration, i.e., when networks in the host country are not yet well developed due to the small numbers and/or geographical dispersion of the migrants from a given home country (Massey et al., 1990). The structural approach to return migration argues that return is not decided solely by reference to the individual experience of the migrant, but also with reference to social and institutional factors in their countries of origin, which influence the reintegration process of returnees. This approach explains that the process of readjustment into the country of origin takes time and depends on the duration of the migration experience. At the same time, extending the duration of stay allows migrants to acquire and diversify their skills in the likelihood of utilizing them on their return (Dustmann, 2003).

According to the transnationalist approach, returnees prepare for their reintegration at home through regular visits to their home countries (Portes, 1999). They typically retain strong links with their home countries and periodically send remittances to their households. The regular contacts they maintain with their home country households, as well as their visits home, assist transnational mobility (Portes, 1999), allowing their return to be better prepared and organized. In line with this hypothesis, Collier, Piracha and Randazzo (2011) found that migrants who decided to return had a higher propensity to remit for investment purposes and remit more as the time spent abroad increased. The 
literature identifies the preparedness of the migrant to return as an important determinant of return. The preparedness to return is determined not only by the willingness of migrants to return home, but also by their readiness to return, i.e., the gathering of sufficient resources and information about post-return conditions at home. Accordingly, a labor migrant whose experience of migration was optimal, i.e., that enabled the desired levels of investment in human capital and accumulation of financial capital, will have a higher level of preparedness than the labor migrant whose experience of migration was too short to achieve those levels (King, 1986; Dustmann, 2003). The strength of family ties is considered to play a positive and significant role in explaining the decision to remit and hence to return. Migrants who intend to return to their home country have also been found to be more likely to remit regularly and invest in their home country (Dustmann and Mestres, 2010, Hinks and Davies, 2015). This may reflect an insurance motive, as migrants consider the readjustment cost upon return and seek (extended) family assistance. Especially related to these latter two approaches is return migration following retirement from the host country's labor market.

Dustmann and Görlach (2015) have attempted to synthesize the above approaches into a general conceptual framework for analyzing return migration based upon the proposition that migrants in each period compare the anticipated benefits from remaining in the host country with those of returning. Based upon their analysis, we specify a binary probit model. The probability $(\operatorname{Pr})$ of a migrant returning home can be explained by the following model:

$\operatorname{Pr}\left(Y=1 \mid X_{i}\right)=\Phi\left(\beta_{i} X_{i}\right)$

where dependent variable $Y$ equals one if the migrant plans to return home in the next five years and 0 otherwise; $\Phi$ is the cumulative distribution function of the standard normal distribution and $\beta_{i}$ are the parameters of the explanatory variables $X_{i}$. The latter consist of three groups of variables that may affect the probability of return migration: the personal characteristics of the migrant; their 
experience in the host country and their preparedness for return. In the following section we identify the specific variables included in these three groups.

\section{Data and Descriptive Statistics}

In the absence of a recent population census, the 2009 Kosovo Migration Survey was conducted on a sample of households selected for the 2009 Household Budget Survey conducted by the Kosovo Agency of Statistics. The Kosovo master sampling frame was stratified by seven regions, urban and rural areas, and a systematic sample of Enumeration Areas (EAs) was selected with equal probability within each stratum at the first stage. The data set for the Migration Survey included a total of 2,024 households resulting in a sample of 12,314 individuals. Weights (expansion factors) were calculated and used in the descriptive and econometric analyzes in order to provide estimates that are valid at the national and urban/ rural levels. To examine the determinants of return migration, individual data on migrants aged $15+$ are used, as reported by household heads living in Kosovo. Variable definitions and summary statistics are provided in Table 1.

The independent variables can be classified into three categories: personal characteristics, experience in host country and preparedness for return. From the question on the likelihood of the migrant returning in the next five years a dichotomous variable was created equal to zero indicating that the migrant is not likely or not very likely to return and equal to one if the migrant is likely or very likely to return in the next five years. The survey indicates that about 12 percent of migrants were likely to return in the following five years. 
Table 1: Variable Definitions and Descriptive Statistics

\begin{tabular}{|c|c|c|c|}
\hline & $\begin{array}{l}\text { Continuous } \\
\text { variables }\end{array}$ & $\begin{array}{c}\text { Dummy } \\
\text { variables }\end{array}$ & \\
\hline Explanatory variables & Average & $\%$ & $\begin{array}{c}\text { No. of } \\
\text { observations }\end{array}$ \\
\hline \multicolumn{4}{|l|}{ Individual characteristics } \\
\hline Gender: $(1=$ male $)$ & & 65 & 1,364 \\
\hline Migrant's age & 34 & & 1,337 \\
\hline Location of migrant's household: ( 1 urban) & & 31 & 1,424 \\
\hline Marital status (=1 married) & & 76 & 1,362 \\
\hline $\begin{array}{l}\text { Secondary education( }=1 \text { if migrant completed at } \\
\text { least secondary education })\end{array}$ & & 53 & 1,330 \\
\hline $\begin{array}{l}\text { Work as a reason for migration: ( }=1 \text { migrated for } \\
\text { working purposes) }\end{array}$ & & 55 & 1,328 \\
\hline \multicolumn{4}{|l|}{ Experience of the migrant in the host country } \\
\hline Employment status: (=1 employed) & & 58 & 1,364 \\
\hline Education acquisition while abroad: ( $=1$ if yes $)$ & & 11 & 1,319 \\
\hline Migration duration in years & 11.6 & & \\
\hline Residential status: $(1=$ permanent $)$ & & 78 & 1,424 \\
\hline \multicolumn{4}{|l|}{ Measures for preparedness of the migrant to return } \\
\hline $\begin{array}{l}\text { Whether migrant has family abroad: } \\
\text { (=1 a migrant has a family abroad) }\end{array}$ & & 88 & 1,038 \\
\hline $\begin{array}{l}\text { Migrant sent remittances: }(=1 \text { migrant has sent } \\
\text { remittances since January 2008) }\end{array}$ & & 44 & 1,358 \\
\hline $\begin{array}{l}\text { Expectations of migrant visiting Kosovo in next } \\
\text { two months: (= } 1 \text { migrant is expected to visit } \\
\text { Kosovo) }\end{array}$ & & 35 & 1,347 \\
\hline $\begin{array}{l}\text { Migrant communicated with family at home } \\
\text { within last month (=1 yes) }\end{array}$ & & 98 & 1,424 \\
\hline $\begin{array}{l}\text { Migrant invested in real estate and/or for business } \\
\text { purposes: (=1 migrant has invested in real estate/ } \\
\text { business) }\end{array}$ & & 5 & 1,424 \\
\hline $\begin{array}{l}\text { Migrant is expected to invest in business in } \\
\text { Kosovo: ( } 1 \text { migrant expected to invest in } \\
\text { business). }\end{array}$ & & 14 & 966 \\
\hline
\end{tabular}

\section{Personal Characteristics}

Variables for gender, age, age squared and the location of the Kosovo household are included in the regression model. Among the migrants, 35 percent were female, the average age was 34 years and 69 percent of them originated from rural areas. A dummy variable was created equalling one if married and zero 
otherwise: 24 percent of the migrants were not married at the time the survey took place. To assess the impact of educational attainment on the probability of return, a binary variable was created equal to one for migrants who completed at least secondary education and 0 if lower than secondary education. The data show that 53 percent of the migrants completed secondary or a higher level of schooling, while just five percent completed tertiary education. A dummy variable is deployed equalling one if the individual initially migrated for workrelated reasons, implying that economic conditions motivated the migration decision. Around 55 percent of the migrants were in this category.

\section{Experience in Host Country}

A dummy variable measures whether a migrant was employed at the time of the survey; nearly 60 percent of the migrants were employed in host countries. The data enables us to examine whether human capital gained abroad increases the likelihood of a migrant's return. A continuous variable was created by subtracting the highest level of education of a migrant prior to migration from the current level of education (the question addressed was to indicate the highest level of education, not number of years in education). A non-zero, i.e., a positive number, implies that the migrant enhanced her/his educational level whilst abroad. Just above ten percent of the migrants were in this latter category, the average increase being one level of education (e.g., moving from completed secondary to completed higher education). To identify the residential status of a migrant, a further dummy variable equals one if the migrant had permanent resident status and zero otherwise. A large majority of the migrants in the sample had permanent resident status (78 percent). Potentially, this variable could have a positive or negative impact. It may be expected that migrants with permanent status have settled down and hence are less likely to return, whereas on the other side having permanent status could enhance their earnings and reduce their relative deprivation (assuming they migrated for work-related reasons). Previous research suggests that the former effect dominates, with, for example, Borodak 
and Piracha (2013) finding that Moldavian emigrants without legal residency were more likely to return.

\section{Preparedness for Return}

It is expected that migrants who have their close family (i.e., wife/husband and children) abroad are less likely to return and, to assess this hypothesis, a dummy variable was created equalling one if the migrant had their family abroad and zero if their immediate family remained in Kosovo. Nearly 90 percent of migrants had their close family members abroad with them.

As discussed in Section 2, previous research suggests that migrants who send remittances are more likely to return. To investigate this hypothesis, a dummy variable is deployed equal to one if the migrant had sent remittances to the household since January 2008 and zero otherwise. The data reveal that 44 percent of the migrants did remit during the reference period. It is expected that migrants who invest in real estate in Kosovo, i.e., buying a house/apartment, acquiring land for a future dwelling and/or investment in business oriented projects, are more likely to return. This proposition is examined using a dichotomous variable distinguishing between migrants that had invested in such assets $(=1)$ and those that had not $(=0)$. The data show that only five percent of the migrants had acquired such assets. The interviewees were also asked about the likelihood that each migrant would invest in a business in Kosovo. From this question a dummy variable was created equal to one if the migrant was likely or very likely to invest and zero otherwise. About 15 percent of the migrants were expected to invest in business in Kosovo.

The NELM stipulates that attachment to the home country is another motive for return migration (Dustmann, 2003 and Dustmann and Weiss, 2007). Accordingly, it is expected that visits and other contacts with their home country to facilitate and strengthen family ties and hence are associated with a higher probability of migrants returning home. Nearly two thirds of the migrants 
were expected to visit Kosovo in the following two months, highlighting that most Kosovo migrants are closely tied to their families at home. This high share of migrants expected to visit Kosovo within the following two months was as anticipated, given that the majority of visits from migrants in Kosovo take place during the summer period and the survey was conducted during May and June.

In the theoretical section it was explained that one motivation behind migration may be relative deprivation, i.e., migration not only occurs to improve income in absolute terms, but also to increase income relative to others in the country of origin. From this theoretical point of view, it may be expected that the longer the stay abroad, the greater the period over which income has been earned, contributing to a narrowing of that gap. On the other hand, according to the network theory, return migration is more likely to occur in the early stages of migration, i.e., when networks are not yet well developed. To examine which of these propositions, if either, applies in the case of Kosovo, a continuous variable is included in the model measuring the length of stay abroad in years. The average uncompleted migration duration was 12 years.

In common with most other studies of return migration, there are two main weaknesses in the data used in this study. Firstly, we do not have data on actual return migration, only the expectations of heads of households in Kosovo. Secondly, as in Hinks and Davies's (2014) study of Romanian return migrants, we are not able to control neither for the initial selection into migration nor to investigate the possibility that the return decision is endogenous. Dustmann and Kirchkamp (2002) and Dustmann (2003) analyzed the determinants of the optimal migration duration, extracting data from a survey of Turkish immigrants to Germany. In the survey, migrants were asked about their return intentions and if the migrants responded that they wished to return to their home country, they were asked to specify the number of years they intended to remain in the host country. However, the data used in our regression analyzes do not allow us to calculate the optimal migration duration since intentions to return refer to plans of the migrant to return in the next five years and not in which year 
he/she is thought to be planning to return. Démurger and Xu (2013) utilized a probit model similar to the one adopted in this paper, with migration duration being captured through a variable indicating the age of the migrants and the age when they migrated. To check whether the results from the probit estimation are influenced by the migration duration variable, a reduced model excluding the migration duration variable was undertaken. In the reduced model, the only change was that the communication variable became insignificant, whereas all the other results remained identical.

Using data from 2012, Kotorri et al. (2013) examined the determinants of return migration for Kosovo, though unlike our approach the household was modelled as the decision-making unit. The findings of Kotorri et al. (2013) suggest that households with average levels of per capita income, lower shares of household members in employment, lower shares of females, those that consist of more than one member, those that have a lower level of socio-economic integration and that have emigrated during the war are more likely to return. Although applying a different estimation technique, our findings, discussed in the next section, are broadly similar to those of Kotorri et al. (2013).

\section{Empirical Findings: Determinants of Return Migration}

The model is estimated by maximum likelihood and, to quantify the impact of explanatory variables, marginal effects were obtained (Table 2), and these are interpreted in this section. The chi-squared value generated by the Wald test is 88.93 , with a p-value of 0.000 , implying that explanatory variables included in the model result in a statistically significant improvement in the fit of the model.

The results suggest that there is no gender difference in the probability of return. There is a negative association between the age and probability of a migrant to return. However, the relationship is non-linear, i.e., the age squared variable has a positive sign. Following the instructions provided in Wooldridge (2002), a 
turning point (the maximum of the function) was estimated. This is calculated as the coefficient of the age variable over twice the absolute value of the coefficient of the age squared term. The maximum function is calculated to be at the age 29, which implies that there is a negative relationship up to 29 years of age and then the relationship becomes positive.

Table 2: Determinants of Return Migration, Weighted Results

\begin{tabular}{|c|c|c|c|c|}
\hline Explanatory variables & $\mathrm{dy} / \mathrm{dx}$ & & $\mathbf{z}$ & $\mathbf{P}>|\mathbf{z}|$ \\
\hline \multicolumn{5}{|l|}{ Individual characteristics } \\
\hline Gender: $(1=$ male $)$ & -0.008 & & -0.20 & 0.843 \\
\hline Migrant's age & -0.016 & ** & -1.99 & 0.047 \\
\hline Age squared & 0.000 & $* * *$ & 2.69 & 0.007 \\
\hline Location of migrant's household: $(=1$ urban $)$ & -0.014 & & -0.64 & 0.521 \\
\hline $\begin{array}{l}\text { Secondary education ( = } 1 \text { if migrant completed at least secondary } \\
\text { education) }\end{array}$ & 0.048 & * & 1.80 & 0.073 \\
\hline $\begin{array}{l}\text { Work as a reason for migration: (=1 migrated for working } \\
\text { purposes) }\end{array}$ & 0.066 & $* *$ & 2.32 & 0.020 \\
\hline \multicolumn{5}{|l|}{ Experience of the migrant in the host country } \\
\hline Employment status: $(=1$ employed $)$ & -0.016 & & -0.43 & 0.666 \\
\hline Education acquisition while abroad: ( 1 if yes) & 0.043 & $*$ & 1.65 & 0.099 \\
\hline Migration duration in years & -0.005 & $* * *$ & -2.73 & 0.006 \\
\hline \multicolumn{5}{|l|}{ Measures for preparedness of the migrant to return } \\
\hline Residential status: ( = 1 permanent) & -0.152 & $* * *$ & -2.78 & 0.005 \\
\hline $\begin{array}{l}\text { Whether migrant has family abroad: (=1 migrant has a family } \\
\text { abroad) }\end{array}$ & -0.081 & $*$ & -1.68 & 0.094 \\
\hline $\begin{array}{l}\text { Migrant sent remittances:( = } 1 \text { migrant has sent remittances since } \\
\text { January 2008) }\end{array}$ & -0.044 & & -1.23 & 0.219 \\
\hline $\begin{array}{l}\text { Expectations of migrant visiting Kosovo in next two months: } \\
\text { (= } 1 \text { migrant is expected to visit Kosovo) }\end{array}$ & 0.127 & $* * *$ & 4.08 & 0.000 \\
\hline $\begin{array}{l}\text { Migrant communicated with family at home within last month } \\
(=1 \text { yes })\end{array}$ & 0.055 & $* *$ & 1.88 & 0.060 \\
\hline $\begin{array}{l}\text { Migrant invested in real estate and/or for business purposes: } \\
(=1 \text { migrant has invested in real estate/business })\end{array}$ & 0.093 & & 1.15 & 0.250 \\
\hline $\begin{array}{l}\text { Migrant is expected to invest in business in Kosovo: }=1 \text { migrant } \\
\text { expected to invest in business }\end{array}$ & 0.248 & $* * *$ & 3.66 & 0.000 \\
\hline Number of observations & & & & 563 \\
\hline
\end{tabular}

Notes: dy/dx is for discrete change of dummy variable from 0 to $1:^{*},{ }^{* *},{ }^{* * *}$ significance level at 10,5 and 1 percent respectively; marital status dropped due to collinearity.

Interestingly, migrants that had initially migrated for work-related reasons were more likely to return compared to those that had migrated for other reasons. 
This result is consistent with the target-setting behavior anticipated by the NELM approach. Also consistent with this approach is the finding that current employment status did not exert any significant influence on the probability of a migrant returning home.

However, there is evidence that more educated migrants are more likely to return compared to less educated ones (albeit only at 10 percent level of significance). Quantifying the results then compared to migrants that possessed less than secondary education, those that possessed at least secondary education were more likely to return by five percentage points. One explanation for this is again that the more educated ones may receive higher incomes in the host country and hence achieve their targeted level of wealth accumulation earlier. Moreover, the more educated may have better labor market prospects in Kosovo and hence are more likely to return. Those emigrants who had acquired additional education while abroad were more likely to return, suggesting that there may be a significant premium in the home country from the acquisition of human capital in the host country. The positive association between education and probability to return is in line with the NELM approach, i.e., return migration being a logical outcome of a 'calculated strategy' which results from the successful achievement of goals while abroad, i.e., higher incomes, accumulation of savings and human capital (Cassarino, 2004). A positive association between return migration and education has been found, for example, in the studies by Nekby (2006) for migrants leaving Sweden, by Jensen and Pedersen (2007) for all immigrants leaving Denmark - which indicates that acquired education may be highly valued in the origin country, hence facilitating return migration - and by Makina (2012) for Zimbabwean migrants living in South Africa.

Ceteris paribus, the longer the migration duration, the less likely is the migrant to return: other things equal, one additional year of staying abroad on average reduces the probability to return by 0.5 percentage points. This finding is in line with the network theory proposition that return migration is more likely to occur in the early stages of migration when networks in the host country are 
not well developed. Additionally, this finding may reflect the inability of a new migrant to find a job and/or an inability to cover their higher costs of living in the host country. The variable distinguishing between migrants originating from rural and urban areas is not statistically significant. The results indicate that migrants with permanent resident status were less likely to return by 15 percentage points. One explanation could be that those with permanent status are in a position to more easily access 'good' jobs in the host country's labor market and benefit from education and social service provisions in those countries, and consequently are less likely to return. As expected, although at only 10 percent level of significance, migrants that had their families abroad were less likely to return (by 8 percentage points), which may indicate that they had made a decision to permanently resettle with their families. Similarly, Piotrowski and Tong (2012) found for migrants from Thailand that the effects of non-economic family-related factors were as strong in magnitude as the economic effects in determining the probability of return.

Contrary to theoretical predictions, sending remittances back home does not influence the probability of a migrant returning. However, as expected, the stronger the family ties of a migrant with the home country, the more likely the migrant is to return. The results suggest that migrants who were expected to visit Kosovo in the coming two months were more likely to return in the next five years by 13 percentage points. Similarly, migrants that frequently communicated with their families at home were more likely to return. These two findings are in line with one of the propositions of the transnationalist theory - that retaining strong links with their home countries, in this case regular visits, enables migrants to plan their return and reintegration. Similar evidence was found by Hedberg (2009); Bijwaard (2010) and Pungas et al. (2012). Kosovan migrants that expected to invest in businesses in their home country were more likely to return in the next five years by 25 percentage points. This finding is consistent with previous research, which suggests that returning migrants with accumulated financial capital, acquired skills and knowledge are disproportionately likely to 
engage in entrepreneurial activities on return. By investing in the home country, migrants also start preparing for their return.

\section{Conclusions}

One significant contribution of this study is that the evidence on the determinants of return migration to Kosovo is particularly supportive of the NELM approach. Those Kosovans who had initially emigrated for economic reasons were more likely to return and current employment status did not significantly affect the probability of return. A further novel finding is that of a non-linear relationship between age and the probability of return, with that probability increasing with age after an individual reaches the age of 29. In line with the network theory approach, the longer the migration duration, the lower is the probability that a migrant will return. In contrast with much previous research, more educated migrants are found to be more likely to return, as are those migrants that acquired additional education whilst abroad. The latter suggests that there may be a significant premium in the home country from the acquisition of human capital in the host country, hence the greater willingness to return.

In common with previous findings, Kosovan migrants that possess permanent status and those that have their family abroad are found to have a lower probability of return. Confirming one of the propositions of the transnationalist theory, the results suggest that the stronger the family ties of a migrant measured by frequent visits and regular communication with their home country, the more likely the migrant is to return. One rationale for this finding is that retaining strong links with their home countries enables migrants to better plan and lower the costs of their return. Empirical results reveal that migrants who are expected to invest in businesses in Kosovo are also more likely to return. This finding is consistent with previous research which suggests that returning migrants that have accumulated financial capital, acquired skills and knowledge are more likely to engage in entrepreneurial activities on return. There is no evidence that gender, 
labor market status, location of household in the home country, i.e., rural/urban, or whether a migrant remits or not influence the propensity to return.

McKenzie and Yang (2014), in their comprehensive survey of international research, found little empirical evidence that any of the policies targeting return migrants had significantly affected the level and economic impact of return migration. We are therefore cautious in drawing policy conclusions from our findings above. However, given the relatively large potential benefits from encouraging return migration, we make four observations regarding policy in Kosovo. Firstly, domestic policy should encourage, where possible, the retention of strong ties between emigrants and Kosovo. Policies which lower communication costs between emigrants and their families, lower the cost of sending remittances and favor remittances being utilized for investment in local production not only directly contribute to economic development, but are also likely to have a second round effect of increasing return migration. Secondly, policies should encourage emigrants to acquire education and training in their host country. Such policies include speedy and low cost accreditation of qualifications earned abroad for migrants returning to Kosovo. The Kosovo government should design incentive mechanisms facilitating the flow of migrants' savings and investments into the Kosovan economy, which in turn will also be likely to positively impact their decision to return. The investments of migrants may also be accompanied by know-how and technology acquired and available in the host countries, which could greatly contribute to business development in Kosovo. As the dominant employer in the country, the government of Kosovo itself should signal the value it places on foreign qualifications and expertise in its own hiring and promotion practices. Finally, we note that McKenzie and Yang (2014) found that policies targeting return migration were rarely formally evaluated. We conclude that any major policy initiative in this area should incorporate an evaluation strategy. 


\section{References}

Agunias, Dovelyn Rannveig, 2006, "From a Zero-Sum to a Win-Win Scenario? Literature Review on Circular Migration”, Washington, DC: Migration Policy Institute.

Bhandari, Prem, 2004, "Relative Deprivation and Migration in an Agricultural Setting of Nepal", Journal of Population and Environment, 25(5), pp. 475-499. http://dx.doi.org/10.1023/B:POEN.0000036931.73465.79

Bhaumik, Sumon, Ira Gang and Myeong-Su Yun, 2006, “A Note on Decomposing Differences in Poverty Incidence Using Regression Estimates: Algorithm and Example", IZA Discussion Papers, No. 2262, Bonn: The Institute for the Study of Labor.

Bijwaard, Govert and Qi Wang, 2013, "Return Migration of Foreign Students", IZA Discussion Papers, No. 7185, Bonn: The Institute for the Study of Labor.

Black, Richard, Russell King and Richmond Tiemoko, 2003, "Migration, Return and Small Enterprise Development in Ghana: a Route out of Poverty?", Sussex Centre for Migration Research Working Papers, No. 9, Sussex: Sussex Centre for Migration Research.

Borjas, George and Bernt Bratsberg, 1996, "Who Leaves? The Outmigration of the Foreign-Born”, Review of Economics and Statistics, 78(1), pp.165-176. http:// dx.doi.org/10.2307/2109856

Borodak, Daniela and Matloob Piracha, 2013, "Who Moves and For How Long? Determinants of Different Forms of Migration”, IZA Discussion Papers, No. 7388, Bonn: The Institute for the Study of Labor.

Carletto, Calogero, Benjamin Davis, Marco Stampini, Stefano Trento and Alberto Zezza, 2004, "Internal Mobility and International Migration in Albania”, ESA Working Papers, No. 04-13, Rome: The Food and Agriculture Organization of the United Nations. 
Cassarino, Jean Pierre, 2004, “Theorising Return Migration: the Conceptual Approach to Return Migrants Revisited", International Journal on Multicultural Societies, 6(2), pp. 253-279.

Cassarino, Jean Pierre, 2008, "Conditions of Modern Return Migrants, Editorial Introduction”, International Journal on Multicultural Societies, 10(2), pp. 95-105.

Clemens, Michael and McKenzie, David, 2014, "Why Don't Remittances Appear to Affect Growth?", World Bank Policy Research Working Papers, No. 6856, Washington, D.C.: The World Bank.

Clemens, Michael, Çağlar Ozden and Hillel Rapoport, 2014, "Migration and Development Research is Moving Far Beyond Remittances", Centre for Global Development Working Papers, No. 365, Washington, D.C.: Centre for Global Development.

Collier, William, Matloob Piracha and Teresa Randazzo, 2011, "Remittances and Return Migration", IZA Discussion Papers, No. 6091, Bonn: The Institute for the Study of Labor.

Démurger, Sylvie and Hui Xu, 2013, "Left-Behind Children and Return Decisions of Rural Migrants in China”, IZA Discussion Paper, No. 7727, Bonn: The Institute for the Study of Labor.

De Vreyer, Philipe, Flore Gubert and Anne-Sophie Robilliard, 2010, "Are There Returns to Migration Experience? An Empirical Analysis using Data on Return Migrants and Non-Migrants in West Africa", Annals of Economics and Statistics, No. 97/98, pp. 307-328.

Dustmann, Christian, 2003, "Return Migration, Wage Differentials, and the Optimal Migration Duration", European Economic Review, 47(2), pp. 353-69. http://dx.doi.org/10.1016/S0014-2921(01)00184-2

Dustmann, Christian and Joseph-Simon Görlach, 2015, "The Economics of Temporary Migrations”, CESifo Working Papers, No. 5188, Munich: CESifo Group Munich. 
Dustmann, Christian and Oliver Kirchkamp, 2002, “The Optimal Migration Duration and Activity Choice after Re-migration", Journal of Development Economics, 67(2), pp. 351-372. http://dx.doi.org/10.1016/S0304-3878(01)00193-6

Dustmann, Christian and Josep Mestres, 2010, "Remittances and Temporary Migration”, Journal of Development Economics, 92(1), pp. 62-70. http://dx.doi. org/10.1016/j.jdeveco.2008.12.002

Dustmann, Christian and Yoram Weiss, 2007, "Return Migration: Theory and Empirical Evidence from the UK", British Journal of Industrial Relations, 45(2), pp. 236-256. http://dx.doi.org/10.1111/j.1467-8543.2007.00613.x

Duval, Laetitia and François-Charles Wolff, 2013, “The Consumption-enhancing Effect of Remittances: Evidence from Kosovo”, WIIW Balkan Observatory Working Papers, No. 107, Vienna: The Vienna Institute for International Economic Studies.

Hedberg, Charlotta, 2009, “Ethnic 'Return’ Migration to Sweden: The Dividing Line of Language", in T. Tsuda (ed.), Diasporic Homecomings: Ethnic Return Migration in Comparative Perspective, pp. 159-185, Stanford, CA: Stanford University Press.

Hinks, Tim and Simon Davies, 2015, "Intention to Return: Evidence from Romanian Migrants”, World Bank Policy Review Working Papers, No. 7166, Washington, D.C.: The World Bank.

International Monetary Fund, 2013, Republic of Kosovo: Fifth Review under the Stand-by Arrangement - Country Report No. 13/379, Washington, D.C.: International Monetary Fund.

Jensen, Peter and Peder Pedersen, 2007, “To Stay or Not to Stay: Out-Migration of Immigrants from Denmark”, International Migration, 45(5), pp. 87-113. http://dx.doi.org/10.1111/j.1468-2435.2007.00428.x

Katz, Eliakim and Oded Stark, 1986, "Labor Migration and Risk Aversion in Less Developed Countries", Journal of Labor Economics, 4(1), pp. 134-149. http:// dx.doi.org/10.1086/298097 
King, Russell, 1986, Return Migration and Regional Economic Problems, London: Croom Helm.

Kosovo Agency of Statistics (KAS), 2012a, People on the Move: an Analysis of International, National and Local Mobility of Kosovo People, Prishtina: KAS.

Kosovo Agency of Statistics (KAS), 2012b, Kosovo Population and Housing Census 2011: Final Results Main Data, Prishtina: KAS.

Kosovo Agency of Statistics (KAS), 2013, Study on Remittance in Kosovo - 2013, Prishtina: KAS.

Kotorri, Mrika, Artane Rizvanolli, Florin Peci, Valon Kotorri, Flaka Çitaku, Preveza Zherka and Dafina Morina, 2013, "Migration and its Impacts from the Perspective of the Economic Development of the Home Country: with Special Reference to Kosova", a project supported by the University of Fribourg and Swiss Agency for Development and Cooperation (SDC), Fribourg: University of Fribourg, Interfaculty Institute for Central and Eastern Europe.

Kuschminder, Katherine and Jessica Butcher, 2012, "Advanced Academic Update Overview: Return, Reintegration”, IS Academy Policy Brief, No. 11, Maastricht: Maastricht Graduate School of Governance.

McCormick, Barry and Jackline Wahba, 2001, "Overseas Work Experience, Savings and Entrepreneurship Amongst Return Migrants to LDCS”, Scottish Journal of Political Economy, 48(2), pp. 164-178. http://dx.doi.org/10.1111/14679485.00192

McKenzie, David and Dean Yang, 2014, "Evidence from Policies to Increase the Development Impacts of International Migration”, World Bank Policy Research Working Paper, No. 7057, Washington, D.C.: The World Bank.

Mahuteau, Stephane and Massimiliano Tani, 2011, "Labour Market Outcomes and Skill Acquisition in the Host Country: North African Migrants Returning Home from the European Union”, IZA Discussion Papers, No. 5441, Bonn: The Institute for the Study of Labor. 
Makina, Daniel, 2012, "Determinants of return migration intentions: Evidence from Zimbabwean migrants living in South Africa", Development Southern Africa, 29(3), pp. 365-378. http://dx.doi.org/10.1080/0376835X.2012.706034

Massey, Douglas, Rafael Alarcon, Jorge Durand and Humberto Gonzalez, 1990, Return to Aztlan: The Social Process of International Migration from Western Mexico, Oakland, CA: University of California Press.

Nekby, Lena, 2006, “The Emigration of Immigrants, Return vs. Onward Migration: Evidence from Sweden”, Journal of Population Economics, 19(2), pp. 197-226. http://dx.doi.org/10.1007/s00148-006-0080-0

OECD, 2008, Return Migration: A New Perspective, Paris: OECD.

Piotrowski, Martin and Yuying Tong, 2010, "Economic and Non-Economic Determinants of Return Migration: Evidence from Rural Thailand”, Population (English edition), 65(2), pp. 333-348. http://dx.doi.org/10.3917/pope.1002.0333

Piracha, Matloob and Florin Vadean, 2010, "Return Migration and Occupational Choice: Evidence from Albania”, World Development, 38(8), pp. 1141-1155. http://dx.doi.org/10.1016/j.worlddev.2009.12.015

Plaza, Sonia and Dilip Ratha, eds., 2011, Diaspora for Development in Africa, Washington DC: The World Bank. http://dx.doi.org/10.1596/978-0-8213-8258-5

Portes, Alejandro, 1999, "Immigration Theory for a New Century: Some Problems and Opportunities" in Hirschman, Charles, Philip Kasinitz and Josh DeWind, eds., The Handbook of International Migration: The American Experience, pp. 2133, New York, NY: Russell Sage Foundation.

Pungas, Enel, Ott Toomer, Tiit Tammaru and Kristi Anniste, 2012, "Are Better Educated Migrants Returning? Evidence from Multi-Dimensional Education Data", Norface Migration Discussion Paper, No. 2012-18, London: Norface Research Program on Migration. 
Quinn, Michael, 2006, "Relative Deprivation, Wage Differentials and Mexican Migration", Review of Development Economics, 10(1), pp. 135-53. http://dx.doi. org/10.1111/j.1467-9361.2005.00306.x

Shaorshadze, Irina and Sachicko Miyata, 2010, "Foreign Remittances and Poverty Reduction in Kosovo", paper presented at the International Conference "Poverty and Social Inclusion in the Western Balkans" organized by the World Bank, Brussels, December 8-9.

Stark, Oded, 1984, "Rural-to-Urban Migration in LDCs: A Relative Deprivation Approach", Economic Development and Cultural Change, 32(3), pp. 475-486. http://dx.doi.org/10.1086/451401

Stark, Oded and David Levhari, 1982, "On Migration and Risk in LDCs", Economic Development and Cultural Change, 31(1), pp. 191-196. http://dx.doi. org/10.1086/451312

Stark, Oded and J. Edward Taylor, 1989, "Relative Deprivation and International Migration”, Demography, 26(1), pp. 1-14. http://dx.doi.org/10.2307/2061490

Stark, Oded and J. Edward Taylor, 1991, "Migration Incentives, Migration Types: the Role of Relative Deprivation”, Economic Journal, 101(408), pp. 11631178. http://dx.doi.org/10.2307/2234433

Stark, Oded and Shlomo Yitzhaki, 1988, "Labour Migration as a Response to Relative Deprivation", Journal of Population Economics, 1(1), pp. 57-70. http:// dx.doi.org/10.1007/BF00171510

Todaro, Michael, 1969, "A Model of Labor. Migration and Urban Unemployment in Less Developed Countries", American Economic Review, 59(1), pp. 138-148.

United Nations Development Program (UNDP), 2010, Kosovo Remittance Study 2010, Prishtina: UNDP.

United Nations Development Program (UNDP), 2012, Kosovo Remittance Study 2012, Prishtina: UNDP. 
United Nations Development Program (UNDP), 2014, Kosovo Human Development Report, Prishtina: UNDP.

World Bank, 2011, Report No. 60590-XK: Migration and Economic Development in Kosovo, Washington DC: World Bank.

Zweig, David, 2005, "Reverse Migration and Regional Integration: Entrepreneurs and Scientists in the PRC", paper presented at the conference "Remaking Economic Strengths in East Asia: Dealing with the Repercussions of Increased Interdependence", organized by Institute of East Asian Studies, University of California, Berkeley, April 8-9.

Zweig, David, Siu Fung Chung and Wilfried Vanbonacker, 2006, "Rewards of Technology: Explaining China’s Reverse Migration”, Journal of International Migration and Integration, 7(4), pp. 449-471.

Wooldridge, Jeffrey, 2002, Econometric Analysis of Cross Section and Panel Data, London: MIT Press. 